\title{
Influence of Sodium and Potassium Levels by Thyroid Hormones Disorder in Sera of Female Patients with Cardiovascular Diseases
}

\author{
Fatin F. Alkazaz ${ }^{*}$, Sura A.Alemami ${ }^{*}$ and Mushtak abd hinadi Al taai ${ }^{* *}$ \\ *Department of Chemistry, Science College, Al-Mustansyria University. \\ Abn Albitar Hosbital.
}

\begin{abstract}
Dysregulation of sodium and potassium has a characteristic role in the development of various cardiovascular disease. In the present study it sought to explore the sodium and potassium influenced by thyroid hormone disorders in sera of patients with cardiovascular disease. The study population consisted of 51 female patients with cardiovascular disease in combination with thyroid dysfunction. Thyroid function disorders were found to have hypothyroidism in $47 \%$ of patients and hyperthyroidism in 53\% of patients. A significant increase in sodium and potassium concentrations were found in both patient groups. A positive significant correlation was observed between $\mathrm{Na}$ concentration and T4 level in sera of patients with hyperthyroidism while a significant negative correlation was found between $\mathrm{Na}$ concentration and TSH level in sera of patients with hypothyroidism.
\end{abstract}

Keyword: cardiovascular ,thyroid, sodium, potassium.

\section{Introduction}

Cardiovascular diseases refers to the class of diseases that involve the heart or blood vessels, such as coronary heart disease, angina, heart attach, and stroke ${ }^{(1),(2)}$. These diseases have similar causes, mechanisms, and treatment ${ }^{(2)}$.

The heart is a major target organ for thyroid hormone action ${ }^{(3)}$. Many symptoms and signs recognized in patients with overt hyperthyroidism and hypothyroidism are due to the increased or reduced action of thyroid hormone on the heart and the vascular system, respectively ${ }^{(4)}$. Both hyperthyroidism and hypothyroidism produce changes in cardiac contractility, myocardial oxygen consumption, cardiac output, blood pressure, and systemic vascular resistance ${ }^{(5)}$.

On the other hand it is becoming increasingly apparent that acute and chronic cardiovascular disease may be altered by thyroid hormone metabolism and contribute to cardiovascular impairment ${ }^{(6)}$. Most of the molecular and cellular mechanisms responsible for the cardiovascular effects of thyroid hormone have been clarrified ${ }^{(7)}$. Total thyroxin $\left(\mathrm{T}_{4}\right)$ and total triodthyronine $\left(\mathrm{T}_{3}\right)$ are synthesized by the thyroid gland in response to TSH .The thyroid gland primarily secrets $\mathrm{T}_{4}$ (85\%), which is converted to $\mathrm{T}_{3}$ by 5 monodeiodination in the liver, kidney, and skeletal muscle ${ }^{(8),(9)}$. The heart relies mainly on serum $\mathrm{T}_{3}$ because no significant myocyte intracellular deiodinase activity takes place, and it appears that $\mathrm{T}_{3}$ and not $\mathrm{T}_{4}$, is transported into the myocyte ${ }^{(10)}$. Thyroid hormones may exert both genomic and nongenomic effects on cardiac myocytes ${ }^{(4)}$.The genomic effects of thyroid hormone are mediated by the transcriptional activation or repression of specific target genes that encode both structural and functional proteins ${ }^{(11)}$. Those includes sarcoplasmic reticulum Ca-ATPase, and its inhibitor phospholamban, $\alpha$-myosin heavy chain, $\beta$ myosin heavy chain, and the ion channels sodium potassium ATPase (Na, K-ATPase), the voltage-gated, potassium channels, and the sodium calcium exchanger ${ }^{(6),(12)}$. Thyroid hormone also has nongenomic effects on the cardiac myocyte and on the systemic vasculature ${ }^{(13)}$. These effects of $\mathrm{T}_{3}$ can occur rapidly and do not involve mediated transcriptional events ${ }^{(14),(15)}$.

These $T_{3}$-mediated effects include changes in various membrane ion channels for sodium, potassium, and calcium, effects on actin polymerization, adenine nucleotide translocater1 in the mitochondrial membrane, and a variety of intracellular signaling pathways in the heart and vascular smooth muscle cells ${ }^{(14),(15)}$. Together the nongenomic and genomic effects of $\mathrm{T}_{3}$ act in concert to regulate cardiac function and cardiovascular hemodynamics ${ }^{(13)}$.

The aims of the present study is to evaluate the influence of thyroid hormone on sodium 
and potassium levels in sera of female patients with cardiovascular disease.

\section{Subjects and Methods}

Subjects: The study samples consisted of 40 healthy individuals as a control group and 51 female patients with cardiovascular diseases of different types in combination with thyroid dysfunction attending $\mathrm{Al}$ Bittar Hospital in Baghdad city during( May - September) and diagnosis by Dr. Ali Abdul Amir .

Serum Sampling:- Venous blood $(5 \mathrm{ml})$ were taken from healthy donors and patients. Blood samples were centrifuged at (3000 rpm)for $10 \mathrm{~min}$, after coagulation serum thus separated and stored at $-20^{\circ} \mathrm{C}$ until being used.

\section{Methods:-}

Determination of serum $T_{3}$ and $T_{4}$ levels :Total triodthyronine and total thyroxin in sera of control and patients were determined using Enzyme Linked Fluorescent Assay (ELFA)(Bio Merieux kit)by VIDAS instruments. The assay principle combines an enzyme immunoassay competition method with a final fluorescent detection (ELFA).

Determination of serum TSH level:-Serum TSH of control and patients was determination using Bio Merieux kit\& ELFA technique on the VIDAS instruments. The assay principle combines a one-step enzyme immunoassay sandwich method with a final fluorescent detection (ELFA).

Determination of $\mathrm{Na}$ and $\mathrm{K}$ concentration:Sodium and potassium concentration were determined in the sera of control and patients using flame photometry method.

Statistical Analysis:- The findings were expressed as the mean $\pm \mathrm{SD}$ with standard error. Statistical and correlation analyses were performed using the student t-test, and spearman correlation test respectively. The $\mathrm{P}$ value $<0.05$ was accepted as statistically significant. Spss (for windows, version 10.0) was used for statistical analyses.

\section{Results}

Thyroid hormones $\mathrm{T}_{3}, \mathrm{~T}_{4}, \mathrm{TSH}$ were measured in the sera of the control and patients with cardiovascular disease. The results represented in Table (1) enable us to classify the studied patients with cardiovascular disease into two groups as far as thyroid dysfunction is concerned. Group I with hyperthyroidism, since they showed normal level of TSH with increase levels of $\mathrm{T}_{3}$ and $\mathrm{T}_{4}$ or decreased level of TSH with normal levels of $\mathrm{T}_{3}$ and $\mathrm{T}_{4}$. Group II with hypothyroidism, since they showed normal level of TSH with decrease levels of $T_{3}$ and $T_{4}$ or increase level of TSH with normal levels of $\mathrm{T}_{3}$ and $\mathrm{T}_{4}$.

The mean value presented in Fig.(1) revealed a highly significant increase in serum potassium $(\mathrm{P}<0.01)$ and sodium $(\mathrm{P}<0.01) \quad$ concentrations respectively of both thyroid dysfunction patient groups with cardiovascular disease in comparison with that of the control group.

In order to check the alteration of sodium and potassium levels by thyroid hormones disorder, a correlation study between $\mathrm{T}_{3}, \mathrm{~T}_{4}$ and $\mathrm{TSH}$ with $\mathrm{Na}$ and $\mathrm{K}$ was carried out in the sera of patients with CVD group I who had hyperthyroidism and in the sera of those patients with CVD group II who had hyperthyroidism Table (1).

Table (1)

The overall results of thyroid hormones in the sera of the control and patients with cardiovascular disease.

\begin{tabular}{|c|c|c|c|c|c|c|}
\hline & $\begin{array}{l}\text { Sample } \\
\text { number } \\
\text { (n) }\end{array}$ & Hormones & $\begin{array}{c}\text { Range } \\
\text { nmole /l }\end{array}$ & $\begin{array}{l}\text { Mean } \\
\text { nmol/l }\end{array}$ & $\begin{array}{l}\text { Standard } \\
\text { Deviation } \\
\pm S D\end{array}$ & $\begin{array}{c}\text { Standard } \\
\text { Error } \\
\text { SE }\end{array}$ \\
\hline Control & 40 & $\begin{array}{c}\mathrm{T} 3 \\
\mathrm{~T} 4 \\
\mathrm{TSH} \\
\end{array}$ & $\begin{array}{c}0.8-2.2 \\
58.2-116.3 \\
0.3-4.8 \\
\end{array}$ & $\begin{array}{l}1.6644 \\
89.582 \\
1.9773 \\
\end{array}$ & $\begin{array}{c}0.3821 \\
13.5014 \\
1.0591 \\
\end{array}$ & $\begin{array}{c}.35 \mathrm{E}-02 \\
1.772 \\
0.1367 \\
\end{array}$ \\
\hline $\begin{array}{c}\text { Group I: } \\
\text { Patient with } \\
\text { hypothyroidism }\end{array}$ & 27 & $\begin{array}{c}\mathrm{T} 3 \\
\mathrm{~T} 4 \\
\mathrm{TSH} \\
\end{array}$ & $\begin{array}{c}1.1-2.6 \\
60.1-121 \\
0.05-2.8 \\
\end{array}$ & $\begin{array}{c}1.7433 \\
86.4074 \\
1.0348 \\
\end{array}$ & $\begin{array}{c}0.3974 \\
14.8756 \\
1.0705 \\
\end{array}$ & $\begin{array}{c}7.65 \mathrm{E}-02 \\
2.8628 \\
0.2060 \\
\end{array}$ \\
\hline $\begin{array}{c}\text { Group II: } \\
\text { patients with } \\
\text { hyperthyroidism }\end{array}$ & 24 & $\begin{array}{c}\mathrm{T} 3 \\
\mathrm{~T} 4 \\
\mathrm{TSH}\end{array}$ & $\begin{array}{l}0.2-2.1 \\
54-101 \\
0.55-60\end{array}$ & $\begin{array}{c}1.337 \\
76.775 \\
6.5146 \\
\end{array}$ & $\begin{array}{c}0.4726 \\
12.1118 \\
12.3671 \\
\end{array}$ & $\begin{array}{c}9.65 \mathrm{E}-02 \\
2.4723 \\
2.5244\end{array}$ \\
\hline
\end{tabular}




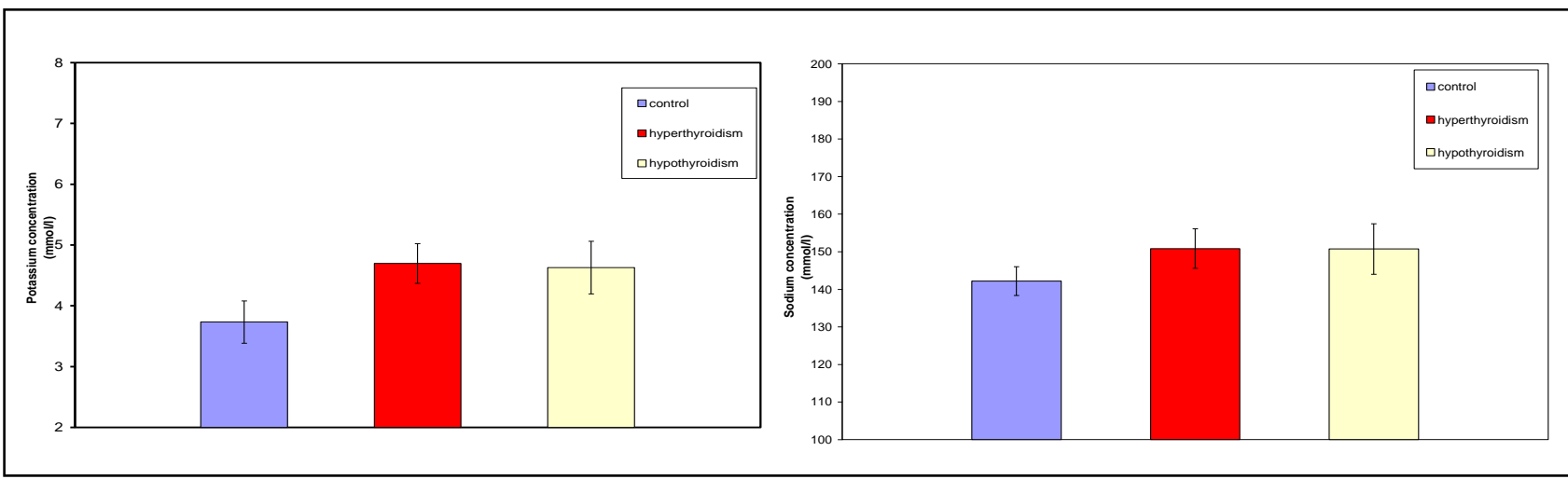

Fig.(1) The mean values of potassium (A) and sodium (B) concentration in sera of control, patients with hyperthyroidism and patients with hypothyroidism.

Table (2)

Correlation Coefficients values of Thyroid hormones with Sodium and potassium in the sera of patients with CVD (groups I \& II).

\begin{tabular}{|c||c||c||c|}
\hline Group & Thyroid hormone & $\boldsymbol{N a}$ & $\boldsymbol{K}$ \\
\hline \hline Group I with & T3 & 0.081 & -0.043 \\
hyperthyroidism & T4 & $0.398^{*}$ & -0.251 \\
& TSH & 0.077 & 0.110 \\
\hline \multirow{2}{*}{ Group II with } & T3 & 0.107 & -0.084 \\
hyperthyroidism & T4 & -0.185 & -0.105 \\
& TSH & $-0.424^{*}$ & -0.062 \\
\hline
\end{tabular}

* correlation is significant at the 0.05 level(2-tailed).

A significant positive correlation was found between $\mathrm{Na}$ and $\mathrm{T}_{4}$ in the sera of patients with CVD (group I) who had hyperthyroidism while a significant negative correlation was found between $\mathrm{Na}$ and TSH in the sera of patients with CVD (group II) who had hyperthyroidism.

\section{Discussion}

The relationship between thyroid status and the cardiovascular system is not undirectional $^{(4)}$. Thyroid hormone metabolism is altered in many patients with acute or chronic cardiac disease, as it is in patients with other nonthyroidal illnesses ${ }^{(6)}$.

Treatment with amidoarone (is an iodine rich antiarrhythmic drug with a structural resemblance to thyroid hormones $T_{3}$ and $T_{4}$ ) may lead to changes hypothyroidism or thyrotoxicosis ${ }^{(16)}$.

In the present study $47 \%$ of the studied patients appear to have hypothyroidism, since they have increase level of TSH with normal levels of $\mathrm{T}_{3}$ and $\mathrm{T}_{4}$ or normal level of TSH with decrease levels of $\mathrm{T} 3$ and $\mathrm{T} 4^{(17)}$. This was in agreement with the result obtained by Hamilton et. al. (1996) who reported that in a population of patients with advanced heart failure, a reduction in $\mathrm{T}_{3}$ with an increase in reverse $T_{3}$ was identified in many patients, with abnormally low ratio of $\mathrm{T}_{3} /$ reverse $_{3}$ being the strongest predictor of mortality $^{(18)}$.Also Tinoco RS. et. al.(2009) showed that thyroid function disorders in patients with chronic stable heart failure were observed in $27.1 \%$ of the subjects: sick euthyroid syndrome $(12.5 \%)$, subclinical hypothyroidism $10.4 \%$ and overt hypothyioidism $(6.2 \%)^{(19)}$. Ascheim DD. and Hryniewicz K. (2002) reported that seven percent of patients with congestive heart failure were found to have primary hypothyroidism and $34 \%$ have a low $\mathrm{T}_{3}$ state $^{(20)}$. In patients with acute myocardial infarction, serum $\mathrm{T}_{3}, \mathrm{~T}_{4}$ decreased while reverse $\mathrm{T} 3$ increased and TSH level remained within normal range ${ }^{(21,22,23,24)}$. Simkoj et. al. (2002) reported that the complex effect of amiodarone on thyroid function ranges from mild abnormalities of thyroid function tests to 
overt thyrotoxicosis or hypothyroidis ${ }^{(25)}$. While Trifanescu R. et. al. (2004) reported that amiodorone-induced thyrotoxicosis developed in 31 cardiac patients $(49.2 \%) ; 17$ patients $(27 \%)$ remained euthyroid patients from iodine deficient areas developed more frequent hyperthyroidism (9\%.vs.40.4\%) at significant lower cumulative doses of amiodarone and never hyperthyroidism. Overt hyperthyroidism prevails (29/31 patients) ${ }^{(26)}$.Mean while this is agreement with the results that obtained throughout the present study where 27 patients with cardiovascular disease (53\%) appear to have hyperthyroidism (Table (1)).

A significant effect of thyroid hormones on the heart results from an interaction with specific nuclear receptors in cardiac myocytes. However, rapid thyroid hormone effects on ion transport functions have been elicited in isolated cardiac myocytes and may be independent of protein synthesis ${ }^{(3)}$. In cardiac muscle, the transarcolemnal sodium gradient established by $\mathrm{Na} / \mathrm{K}$ ATPase activity is essential not only for generating the rapid upstroke of the action potential but also for driving a number of ion-exchange and transport processes crucial for normal cellular function, ion homeostasis and the control of cell volume ${ }^{(27)}$.

Various cardiovascular disease such as ischemic heart disease ,myocardial infarction and ventricular dystrophy are the most common cardiovascular problems .As proved by various studies, dysregulation of sodium $\mathrm{Na}$, potassium $\mathrm{K}$, calcium $\mathrm{Ca}$, has a characteristic role in the development of various cardiovascular diseases. Basic cellular abnormalities in various cardio vascular diseases is an inability to maintain a normal transmembrane gradient ${ }^{(28)}$

The plasma sodium and potassium concentrations were found to be altered in cardiovascular patients. This has been indicated by several previous investigators suggesting that increases in $\mathrm{H}^{+}$exchanger activity might be involved in this functional impairment $^{(29)}$.

In the present study serum sodium and potassium measurements Fig.(1) showed a significant increase $(\mathrm{p}<0.01)$ in serum sodium and potassium concentrations of patients with cardiovascular disease in both groups : group I who had hyperthyroidism and group II who had hypothyroidism. This was in agreement with the result that obtained by En-zhi JIA. et. al. (2007) who indicated that females were at greater risk of hypernalremia and the serum sodium concentration was significantly increase and negatively associated with coronary atherosclerosis ${ }^{(30)}$, on the other hand disagreed with the results obtained by Shahid SM.et.al. (2005) who reported that serum sodium level was significantly decreased and serum potassium level significantly increased in cardiac patients ${ }^{(31)}$. Also the present result disagreed with the results obtained by Harrison TR. (1930) who indicated that plasma and muscle magnesium and potassium concentrations are reduced in heart failure ${ }^{(32)}$.

A non significant correlation was found in the present study between $\mathrm{K}$ concentration and thyroid hormones level in the sera of patients with cardiovascular disease while a significant positive correlation was found throughout this study between $\mathrm{Na}$ concentration and $\mathrm{T}_{4}$ in level in the sera of patients with cardiovascular disease group I who had hyperthyroidism and a significant negative correlation was found between $\mathrm{Na}$ concentration and TSH level in the sera of patients with cardiovascular disease group II who had hypothyroidism (Table (2)).

This finding indicated that $\mathrm{Na}$ ion effected by thyroid hormone changes that occurs in sera of patients with cardiovascular disease while $\mathrm{K}$ ion did not effected by alteration in thyroid hormone level in the sera of the same patients under this study .

\section{References}

[1] Madder S.S. \& Galliart P.L., "Understanding Human Anatomy \& Physiology", Mc Grow Hill Companies, Inc., New York, 2001; $4^{\text {th }}$ ed., p. 232.

[2] Maton ,Anthea. , "Human Biology and Health”, Englewood cliffs, New Jersey : Prentice Hall, 1993, p.256.

[3] Kahaly GJ. \& Dillmann WH., Thyroid Hormone action in the heart. Endocrine Reviews .2003;26(5):704-728.

[4] Fazio S., Palmieri EA., \& Lombardi G., Effects of thyroid hormone on the cardiovascular system. Recent Progress in Hormone Research . 2004;25:31-50. 
[5] Biondi B., Palmieri EA. \&Lombardi G., Effects of thyroid hormone on cardiac function : the relative importance of heart rate, loading Conditions, and myocardial contractility in the regulation of cardiac performance in human hyperthyroidism . J Clin Endocrinol Metab. 2002;87:968974.

[6] Klein I.\& Ojamaa K., Thyroid hormone and the cardiovascular system. The New England Journal of Medicine 2001; 344(7): 501-509.

[7] Ojamaa K.,Klemper JD. \& Klein I. Acute effects of thyroid hormone on vascular smooth muscle. Thyroid 1996;6:505-512.

[8] Maia AL. ,Kim BW., \& Huang SA. , Type 2 iodothyronine deiodinase is the major source of plasma $T_{3}$ in euthyroid humane. J clin Invest. 2005; 115:25242533.

[9] Bianco AC., Satvatore D., Gereben B., \& Berry MJ., Biochemistry, cellular and molecular biology, and physiological roles of the iodothronine selenodeiodinases . Endocrine Rev. 2002; 23:38-89.

[10] Everts ME. Verhoeven FA., \& Bezstarosti K., Uptake of thyroid hormones in neonatal rat cardiac myocytes. Endocrinology. 1996; 137:42354242.

[11] Dillmann WH., Biochemical basis of thyroid hormone action in the heart. Am J Med. 1990; 88(6):626-630.

[12] Dillmann WH., Cellular action of thyroid hormone on the heart. Thyroid 2002; 12:447-452.

[13] Klein I.\& Danzi S., Thyroid disease and the heart. Circulation 2002; 116:17251735.

[14] Davis PJ. \& Davis FB., Nongenomic actions of thyroid hormone on the heart . Thyroid . 2002; 12:459-466.

[15] Hiroi Y;Kim H.H; Ying H.,Rapid nongenomic action of thyroid hormone.Proc Natl Acad Sci USA,2006;103:14104-14109.

[16] Zysko D. \& Gajek J., Thyroid and cardiovascular disorders. Pol Merkur Lekarski. 2004; 16(95):411-414.
[17] Mayne PD.,"Clinical Chemistry in Diagnosis and Treatment", Arnold, London, 2002, $6^{\text {th }}$ ed., pp.160-163.

[18] Hamilton MA. \& Stevenson LW., Thyroid hormone abnormalities in heart failure: Possibilities for therapy. Thyroid 1996; 6(5):527-529.

[19] Tinoco RS., Martine LC., \&Jejeda AO. , Developing thyroid disorders is associated with poor prognosis factors in patients with stable chronic heart failure. International Journal of Cardiology 2009; Feb 8. ( Epub a head of print).

[20] Ascheim DD. \& Hryniewicz K., Thyroid hormone metabolism in patients with congestive heart failure: the low triodothyronine state. Thyroid 2002; 12(6):511-515.

[21] Wiersinga WM., Like I. \& Touber JL., Thyroid hormone in acute myocardial infarction. Clin Enocrinol 1981;14(4):367374.

[22] Franklyn JA., Gammage MD., \& Ramsden DB., Thyroid status in patients after acute myocardial infraction. Clin Sci 1948; 67(6):585-590.

[23] Ohyama T., Nakai A., \&Nagasaka A.,Change in serum thyroid hormone levels in patients with acute myocardial infarction . Nippon Naibunpi Gakkai Zasshi 1987; 63(1):19-25.

[24] Holland FW., Brown PS. JR., \& Weintraub BD. , Cardiopulmonary bypass and thyroid function: a"euthyroid sick syndrome". Ann Thorac Surg. 1991; 52(1):46-50.

[25] Simko J., Barta k., \& Szabo Z., Cardiovascular mainfiestations of thyrotoxicosis and thyroid dysfunction caused by amiodarone. Orv Hetil. 2004; 145(48):2411-2417.

[26] Trifanescu R., Fico S., \& Barbu C., Amiodarone-induced thyroid dysfunction in cardiac patients from areas with iodine deficiency. Rom J Intern Med. 2004; 42(3):595-605.

[27] Fuller W., Parmar V., \&Eaton Ph., Cardiac ischemia causes inhibition of Na/K ATPase by a labile cytosolic compound whose production is linked to oxidant stress. Cardiovascular Research. 2003; 57(4):1044-1051. 
[28] Milionis HJ., Alexandrides GE.\& Liberopoulose EN., Hypomagnesemia and concurrent acid-base electrolyte abnormalities in patients with congestive heart failure. Eur.J.Heart Fail. 2002; 4(2):167-173.

[29] Hayashi M.,Yoshilda T. \& MonhawaT., $\mathrm{Na}^{+}-\mathrm{H}^{+}$-exchanger activity and its gene in the spontar hyoertensive rat kidney. JHypertens. 1997; 15:43-48.

[30] En-Zhi JIA., Zhi-JianYang \& Tie-ing ZHU, Serum sodium concentration is significantly associated with the angiographic characteristicsof coronary atherosclerosis. ActaPharmacologica Sinica 2007; 28(8):1136-1142.

[31] Shahid SM., \&Mahboob T. Integration of ionic hypothesis of non-communicable disorders. Journal of basic \& applied Science. 2005; 1(2).

[32] Harrison C., Pilcher \& Ewing, Studies incongestive heart Failure IV. The potassium content of skeletal and cardiac muscle. J Clin Invest. 1930; 8:325-335.

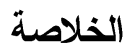

إن عدم انتظام مستوى الصوديوم و البوتاسيوم في الام

له دور مميز في تطور عدد من الأمراض القلبية الوعائية,

ولغرض إيضاح تأثز مستويات الصوديوم و البوتاسيوم

بالتغير ات الهرمونية للارقية في مصول دم المصابات

بمرض القلب الوعائي, تم قياس مستوى هرمونات الدرقية

و تركيز الصوديوم و البوتاسيوم في (T3,T4,TSH)

مصول دم المصابات بمرض القلب الوعائي حيث تضمنت

الدراسة الحالية جمع 51 عينة من المصابات بمرض القلب

الوعائي ولديهن اضطر ابات في هرمونات الدرقية روقد تبين

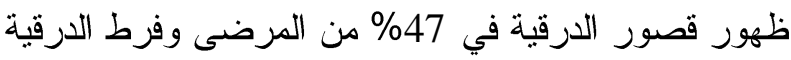

في 53\% من المرضى. أيضا توصلت الدراسة إلى وجود

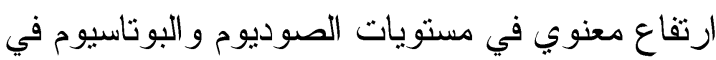

مصول دم كلا المجموعتنين مع وجود علاقة ايجابية معنوية

بين مستوى T4 و الصوديوم في مصول دم المصابات

بأمر اض القلب الوعائي اللاتي لديهن فرط الدرقية في حين

لوحظ أن العلاقة بين مستوى الصوديوم و TSH في مصول

دم المصابات بأمر اض القلب الوعائي اللاتي لديهن قصور الدرقية كانت سالبة معنوية. 